\title{
The Influence of SERVQUAL on Behavioral Intentions of Thai Tourists Travelling in the Thai-Myanmar Border Area
}

\author{
Kanthachai, Nongnout \\ Chiang Rai Rajabhat University \\ E-Mail: nkunthachai@gmail.com
}

\begin{abstract}
The purpose of this research was to study the influence of SERVQUAL in terms of business image and tourist satisfaction, complaints, and behavioral intentions on Thai tourists in the Thai-Myanmar border area. In 500 representative samples, the findings indicated that the majority of respondents were females, aged 20-40 years old, with a bachelor degree. Their occupations were corporate employees, earning an average income of 10,000-20,000 Thai Baht per month. Regarding the effects of SERVQUAL on the building up of the business image and tourist satisfaction, the analysis showed that a good SERVQUAL could effectively increase the behavioral intentions. Conversely, tourists often complained about the less-qualified service received. Notably, rapid ploblem solving regarding the tourists' complaints could increase their behavioral intentions as well. Based on the results, a tourism entrepreneur will benefit more by adoping the research findings to improve his or her service quality, especially in terms of tangible services and the empathy to extend the tourists' behavioral intentions and to meet the tourists' needs, not only in the ThaiMyanmar border area, but also in other areas in the near future.
\end{abstract}

Keywords: Behavioral Intentions, Business Image, SERVQUAL, Thai-Myanmar Border Area, Tourist Satisfaction

\section{INTRODUCTION}

Since the late 1970s, many scholars have studied service quality measured by the SERVQUAL method (GrÖnroos, 1984). This technique consists of five main aspects: reliability, responsiveness, assurance, empathy, and tangibles. The basic focus of this measure is on the quality of services brought to the image of a business. The business image mostly relates to an overview of beliefs, feelings, expectations, and the 
impression of a person toward a place or something else. For example, a function quality is an expression of a servicer directly to a customer while serving him or her. A technique quality focuses on the goods/services provided to a customer or the result of an interaction between a servicer and a customer.

The results of business image creation derived from the function and technique qualities can achieve high customer satisfaction. More pleasures that the customer experiences include the results of assessment, perception, and expectation or the use of the products. However, complaints may occur while using the unqualified products/services, thus causing dissatisfaction. If the complaints do not receive the attention or amendment, the tourists will not use the goods/services anymore. However, if the complaints get noticed or are resolved promptly once the tourists needs, this response can fade the tourist's complaints and lead to increased customer behavioral intention. Tourists are willing to use the services provided and recommend them to other tourists to use/reuse the services.

In particular, many countries, including Thailand, have been emplasized for service quality in the tourism industry, because it is a business that can create more jobs and generate income for the people, community, society, and country. Likewise, approximately 850,000 tourists travelled to the Thai-Myanmar border, Mae Sai SubDistrict, and Chiang Rai Province. This travel could create jobs and generate incomes to the local people about 500 million Thai baht per day (Tipprasong, 2014). This revenue is considered as the main income for the province.

The rapid growth of the tourism industry causes the service quality to decline, resulting in a bad business image from the tourists' perspective. Tourists feel dissatisfied towards the inconvenience of the services received and complain about the unsuitable services. However, if the complaints are immediately responded to, the behavioral intentions of tourists would be created in their mind, attracting the tourists re-visit the attractive places, and vice versa. Therefore, entrepreneurs are required to improve the service quality in the tourism industry (Parasuraman et al., 1988) to meet international standards. Such service quality improvement creates a good business image (GrÖnroos, 1984). This good business image then leads to high satisfaction (Oliver, 1980) without tourists' complaints (Zeithaml et al., 1996). Tourists then exhibit behavioral intentions to re-visit the attractive places (Zeithaml, 1988).

Due to the stated problems, the researchers seek to study the influence of causal variables affecting the behavioral intentions of the tourists who travel to the ThaiMyanmar border area. 


\section{Objective}

This study aimed to investigate the influence of SERVQUAL on behavioral intentions of Thai tourists who travel to the Thai-Myanmar border area.

\section{Conceptual Framework}

The conceptual framework of this research focused on the causal influences of the SERVQUAL, business image, satisfaction, complaints, and behavioral intentions of the tourists. In this study, the tourists' satisfaction and complaints were the intervening variables. The study investigated the direct effect of these two variables as well.

\section{Hypotheses}

$\mathrm{H}_{1}$ : SERVQUAL has a directly positive effect on business image.

$\mathrm{H}_{2}$ : SERVQUAL has a directly positive effect on tourist satisfaction.

$\mathrm{H}_{3}$ : Business image has a directly positive effect on tourist satisfaction.

$\mathrm{H}_{4}$ : Tourist satisfaction has a directly positive effect on tourist complaints.

$\mathrm{H}_{5}$ : Tourist satisfaction has a directly positive effect on behavioral intentions.

$\mathrm{H}_{6}$ : Tourist complaints have a directly positive effect on behavioral intentions.

$\mathrm{H}_{7}$ : SERVQUAL has a directly negative effect on tourist complaints.

$\mathrm{H}_{8}$ : SERVQUAL has a directly positive effect on behavioral intentions.

$\mathrm{H}_{9}$ : Business image has a directly positive effect on tourist complaints.

$\mathrm{H}_{10}$ : Business image has a directly positive effect on behavioral intentions.

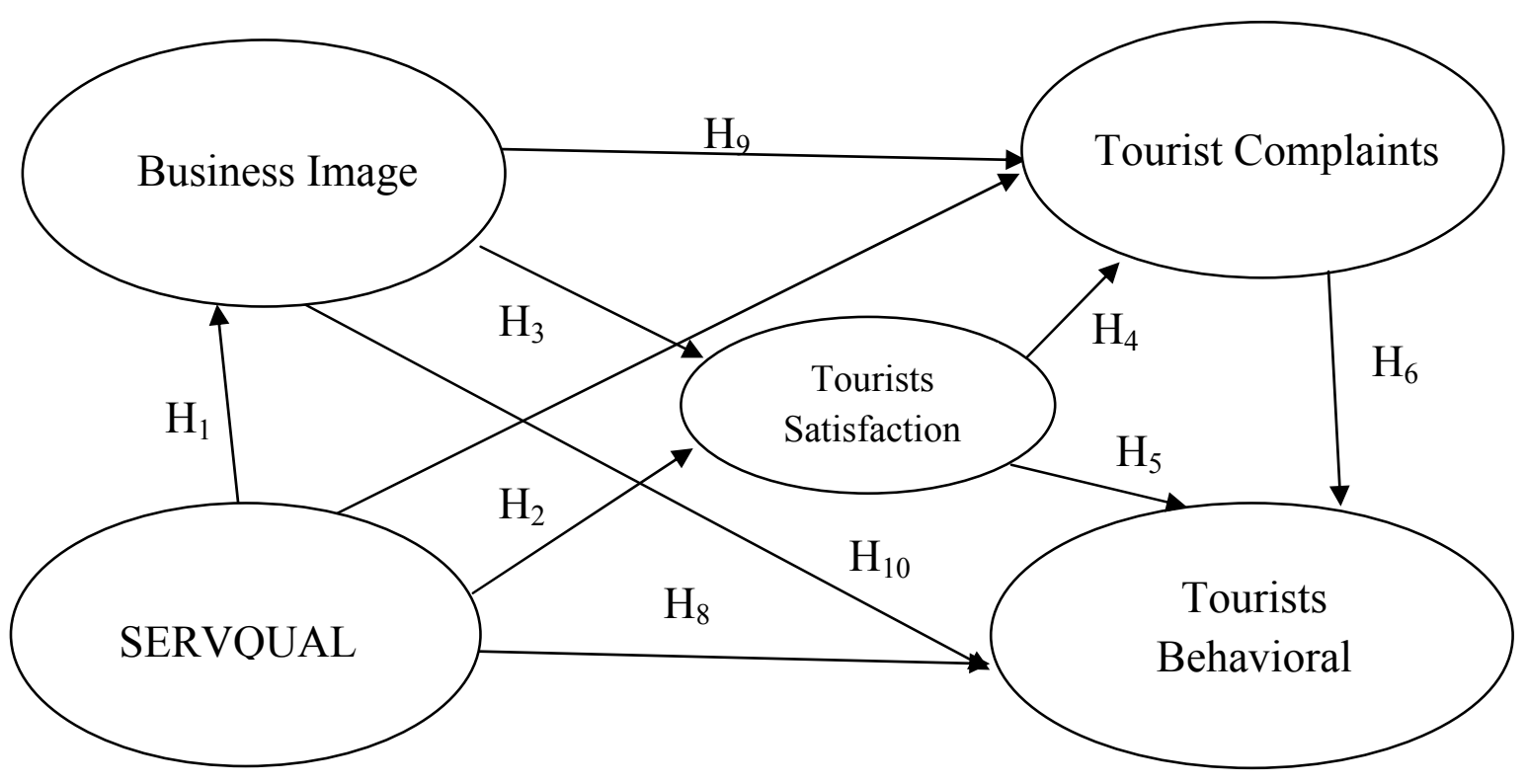

Figure 1 The conceptual framework and hypotheses of the study 


\section{LITERATURE REVIEW}

The literature focused on the service quality, business image, satisfaction, and complaints that affect the behavioral intentions of the domestic tourism in the case study of Chiang Rai Province. The researchers summarized the related concepts with the following details.

\section{Service Quality Theory}

Since the late 1970s, the concept of service quality has been of great interest among the marketers and the general public, because service quality is an idea that can lead to success in competitive businesses around the world. This concept can create some advantage and long profit to the business (Wakefield et al., 2001). Therefore, the service quality is an attitude derived from the comparation between the expectation and the perception of real action.

Based on the concept of consumer behavior, service quality indicates the gap between the expectations of the customer obtained from the service provider and the awareness about the effect of the service among three groups - the executives, the service providers, and the customers (Kotler \& Keller, 2012). These gaps can be categorized into five groups. The first gap is the difference between the expectations of the customers and the recognition of the executive. The second gap is the difference between the recognition of the executive and the terms of service quality. The third gap is the difference between the terms of service quality and the service delivery. The fourth gap is the difference between the service delivery and communication to the customers. The last gap is the difference between perceived service and the expected service. All five gaps affected the assessment of the users toward the service quality, which depends on the size and dimension of the fifth gap. Users will randomly evaluate the service quality provided by the service provider, arising from the inconsistencies between the perceived service and expected service (Soekisno, 2001). The five dimensional service quality is utilized for satisfaction evaluation, consisting of reliability, responsiveness, assurance, empathy, and tangibles. The assessment operation is measured by the service quality factors in recognition of such services (Rajesh, 2010). These factors can be explained through the following assertions: (1) if the service quality is beyond the expectation (PS $>$ ES), the service quality is excellent; (2) if the service quality meets expectations ( $P S=E S$ ), the service quality is good enough; and (3) if the service quality is lower than the expectation (PS $<$ ES), the service quality is not good, which will affect the business image, satisfaction, complaints, and behavioral intention of tourists. 


\section{Business Image Theory}

Business image is one's knowledge and image of something of interest. In particular, the knowledge is information and understanding that it is build up through the synthetic process; this is subjective knowledge (Huang et al., 2014). Likewise, the image is what happens as a result of several factors under the control of the business sector. Considering the business image that relates to a marketing campaign, it can be separated into four categories: (1) product or service image, (2) brand image, (3) institutional image, and (4) wish image or desired image (Kotler, 2000).

In conclusion, the business image is an expression that a servicer provides to a user and the user receives from the servicer while in a service operation. The business image that is expressed by the servicer/user will be showed through recognition, learning, and feeling toward the products/services. After using the products/services, a customer will assess what has been received through the purchase of goods/services and evaluate whether the customer is satisfied or not. If the customer is satisfied with the use of goods/services, satisfaction will occur in the customer's mind. However, if the customer feels dissatisfied, complaints will be displayed instead of satisfaction.

\section{Satisfaction Theory}

Satisfaction refers to the difference between the expectation and the recognition of the person who uses the service. It also refers to a group of people who participate in such a matter. Development of the customer satisfaction's concept found in the expectancy disconfirmation theory is an initial point of the evaluation study on goods and services that have been defined into two basic structures (Gillison, 2012). The first structure includes the expectation element, which is the good service-mind expected from the user. The second structure is the element that is inconsistent with the user's expectation.

Later in 1997, Oliver also proposed a model of an acceptable level of anticipation, explaining that the customers' expectation and perceptible operation had a relationship with the adoption of purposes. This model explains the difference between the anticipation and acceptable level judged by personal feelings which has a direct effect on satisfaction. Tourists' satisfaction has an influence on the behavioral intentions of buying goods/services (Caro \& Garcia, 2007). By contrast, the dissatisfaction may influence the customer to find an alternative choice for the next buying opportunity. GrÖnroos (1984) stated that the perception of good service quality that can meet tourists' satisfaction consists of six parts: (1) professionalism and high skills in providing services, (2) attitudes and behaviors, (3) accessibility to a 
flexible and simple service, (4) trust and honesty about the service providers, (5) compensation, and (6) the reputation of the service providers (GrÖnroos, 1984).

In conclusion, satisfaction considers the users' expectations and perceptions that compare the operating performance provided by a servicer. When the users perceive high expected services, they will have behavioral intentions. When the users get low expected services, they will complain to the service providers.

\section{Complaint Theory}

Complaint in this context refers to the unsatisfactory experience of customers. Customers will find goods/services provided by a company's competitors instead for the purpose of fulfilling high satisfaction (Chen, 2012). The complaint is the unfavored behaviors displayed by the customers. It is derived from unsuitable service quality, bad business image, and a lack of a service-mind of a servicer, resulting in the customer trying to deviate themself from such bad goods/services (Tax \& Brown, 2000).

The complaint results consist of two points. The first result is the switch of service providers which is the unpleasant behavior of the customers toward the providing business. The business trend is gradually declining. Customers prefer to do a business with competitors if there is a better choice proposed. The second results are external and internal responses. The external response is the unpleasant behavior of the customers by making the complaints or appeals when they found the problems on service. Likewise, the internal response is the unbiased act that the customers perform when they find the problems caused by the staff.

\section{Behavioral Intentions Theory}

Behavioral intentions are the intention of repeating the experience and willingness to use a service, recommendation to other tourists to use the service, and re-use of the services (Cao and Chen, 2011). The response's results on behavioral intentions comprise two components: loyalty and pay more. Loyalty refers to the customers' favorite behaviors, such as the business's acceptance, suggesting that other customers should know about the good side of business, word of mouth, and recommendation that other customers use the good products or services (Goodman, 2006). The pay more concept is a favorite behavior of the customers who continuously use the goods/services, even though the price is higher than the competitors. This behavior is the price sensitivity's factor that each customer responds to. The customer will compare the market price based on the reference price paid recently with the 
actual price. When the actual price is less than the reference price, the customer's perception is expected to earn a profit, and vice versa.

\section{METHODOLOGY}

This epistemological research focused on the causal influence of variables on SERVQUAL, business image, satisfaction, and complaints that affected the behavioral intentions to consume the services happily, tell other people to use the service (word of mouth), and re-visit on tour.

\section{Population and Samples}

The population of the study included Thai tourists who traveled at the ThaiMyanmar border area. The sample group was chosen by using probability sampling in multi-stages as follows:

A simple random sampling (SRS) was employed to collect the data from the onetime visiting tourists.

A convenience sampling was theorically used to collect the data from the multientry tourists, totalling 500 sample sizes.

\section{Data Collection Tools}

This study used questionnaires to collect data from Thai tourists who visit the Thai-Myanmar border area. The questionnaires were separated into 6 parts. Part I surveyed the demography and general information of the tourists. Part II evaluated the service quality that the Thai tourists received. Part III asked for the tourists' opinions towards the border area. Part IV assessed the satisfaction of Thai tourists. Part V evaluated the level of complaints. Finally, Part VI measured the level of behavioral intentions.

Moreover, the study tested the tool's quality by examining (1) the content validity, done by the specialists with the results of minimum score 0.75 and maximum score 1.00, and (2) the reliability, in which we examined 30 samples done by the Cronbach alpha with the alpha coefficients results of more than 0.7 (Nunnally, 1978).

\section{Data Analysis}

The data was analyzed in two steps; the first step was the confirmatory factor analysis (CFA), and the second was analysis using the AMOS model with Latent variables (DeVellis, 1991) used to illustrate the causal influences of SERVQUAL, business image, tourist satisfaction, tourist complaints, and behavioral intentions of Thai tourists who traveled to the Thai-Myanmar border area by using the Structural Equation Model: SEM. 


\section{FINDINGS}

The respondents were 20-40-year-old female graduates with a bachelor degree whose average monthly income was 10,000-20,000 baht. The results of the confirmatory factor analysis by multi-factors congeneric model are shown in Table 1.

The hypothesis testing after adjusting the new model shows that $\mathrm{H}_{1}$ SERVQUAL has a direct positive effect on the business image, $\mathrm{H}_{4}$ tourist satisfaction has a direct effect on the tourist complaints, and $\mathrm{H}_{10}$ business image has a direct positive effect on the tourist behavioral intentions; these are well fitted with the hypothesis with a statistical significance at $.001 . \mathrm{H}_{2}$ SERVQUAL has a direct positive effect on tourist satisfaction and $\mathrm{H}_{6}$ tourist complaints has a direct positive effect on the tourist behavioral intention; these are well fitted with the hypothesis with a statistical significance at .01. In addition, $\mathrm{H}_{5}$ tourist satisfaction has a direct positive effect on tourists' behavioral intention, which is well fitted with the hypothesis, with a statistical significance at .05 . On the other hand, $\mathrm{H}_{3}$ business image has a direct positive effect on tourist satisfaction, $\mathrm{H}_{7}$ SERVQUAL has a direct negative effect on the tourist complaints, $\mathrm{H}_{8}$ SERVQUAL has a direct positive effect on tourist behavioral intention, and $\mathrm{H}_{9}$ business image has a direct effect on the tourist complaints; these are not fitted with the hypothesis because entrepreneurs have already improved their service quality in terms of tangible services, empathy, assurance, responsiveness, and reliability respectively. Consequently, tourists perceive a positive business image, particularly regarding both function quality and technique quality. The relationship between the factors above is shown in Figure 2.

Table 2 shows the results of the hypothesis testing of the adjusted model by analyzing the direct effect, indirect effect, and combined effect among the various variables. It shows that SERVQUAL has a positive direct effect on business image and satisfaction with weights of .775 and .643 respectively, and a negative effect for complaints and behavioral intentions, weighted -.586 and -.294 respectively. Business image has a direct positive effect on satisfaction, complaints, and behavioral intention with weights of $.074, .023$ and .471 respectively. Satisfaction has a direct positive effect on complaints and behavioral intentions with weights of 1.432 and .422 respectively, and complaints has a direct positive effect on behavioral intention with a weight of .473. However, the SERVQUAL also has a direct positive effect on behavioral intentions through satisfaction and complaints with a weight of .436, and SERVQUAL has an indirect positive effect on behavioral intentions through business image with a weight of .473. Lastly, SERVQUAL has an indirect effect on behavioral intentions through satisfaction with a weight of .271. Entrepreneurs should improve 
SERVQUAL to reduce complaints, as SERVQUAL directly and negatively influences both tourists' complaints and tourists' behavioral intentions.

Table 1 The Comparison of Statistical Consensus of Empirical Data Models between The Hypothesis Model and Adjusted Model

\begin{tabular}{llllll}
\hline Test statistics & $\begin{array}{l}\text { Models } \\
\text { based on } \\
\text { hypothesis }\end{array}$ & $\begin{array}{l}\text { Modified } \\
\text { model }\end{array}$ & $\begin{array}{l}\text { Standard } \\
\text { score }\end{array}$ & $\begin{array}{l}\text { The } \\
\text { consistency } \\
\text { of the model } \\
\text { based on } \\
\text { hypothesis }\end{array}$ & $\begin{array}{l}\text { The } \\
\text { consistency } \\
\text { of adjusted } \\
\text { model }\end{array}$ \\
\hline chi-square $\left(\chi^{2}\right)$ & 1095.90 & 582.7 & - & - & - \\
$d f$ & 692 & 633 & - & - & - \\
$p$-value & .000 & .924 & $>.05$ & not-fitted & well-fitted \\
$\chi^{2} / d f$ & 1.584 & .921 & $<2.00$ & well-fitted & well-fitted \\
GFI & .895 & .945 & $>.90$ & not-fitted & well-fitted \\
AGFI & .882 & .932 & $>.09$ & well-fitted & well-fitted \\
CFI & .807 & 1.000 & $>.95$ & not-fitted & well-fitted \\
RMR & .032 & .022 & $<.08$ & well-fitted & well-fitted \\
RMSEA & .034 & .000 & $<.08$ & well-fitted & well-fitted \\
\hline
\end{tabular}

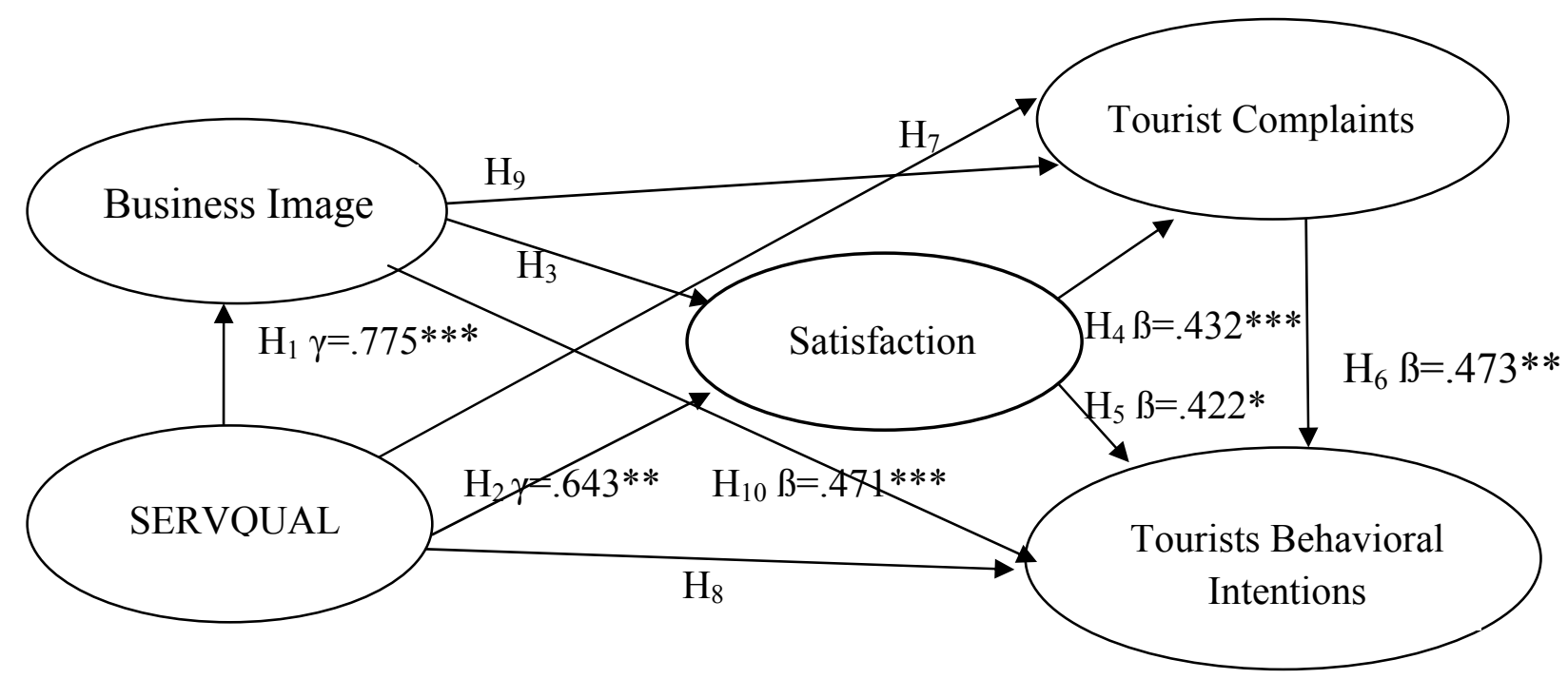

Figure 2 The Path Analysis of Hypothesis Testing, Direct Influence, Indirect Influence among The Various Variables 
SERVQUAL also has a direct effect on the positive-negative and an indirect influence on the behavioral intention in Table 2.

Table 2 The Analysis of A Direct Effect, Indirect Effect, and Combined Effect among The Various Variables.

\begin{tabular}{l|c|c|c|c|c|c|c|c|c|c|c|c|c}
\hline $\begin{array}{c}\text { Observe } \\
\text { Variables }\end{array}$ & \multicolumn{3}{|c|}{ Business image } & \multicolumn{3}{|c|}{ Satisfaction } & \multicolumn{3}{c|}{ Complaint } & \multicolumn{3}{c}{$\begin{array}{c}\text { Behavioral } \\
\text { intention }\end{array}$} \\
$\begin{array}{l}\text { Latent } \\
\text { Variables }\end{array}$ & DE & IE & TE & DE & IE & TE & DE & IE & TE & DE & IE & TE \\
\hline SERVQUAL & .775 & - & .775 & .643 & .057 & .700 & -.586 & 1.020 & .434 & -.294 & .866 & .572 \\
\hline Business & - & - & - & .074 & - & .074 & .023 & .106 & .128 & .471 & .092 & .563 \\
\hline Satisfaction & - & - & - & - & - & - & 1.432 & - & 1.432 & .422 & .677 & 1.099 \\
\hline Complaint & - & - & - & - & - & - & - & - & - & .473 & - & .473 \\
\hline Behavioral & - & - & - & - & - & - & - & - & - & - & - & - \\
\hline
\end{tabular}

\section{CONCLUSIONS}

Regarding the demographic data of Thai tourists, the results indicated that the questionnaire respondents were 20-40-year-old female graduates with a bachelor degree. Their careers included corporate employees whose average income per month was 10,000-20,000 baht.

The tourism entrepreneurs can use the research findings to improve their service quality, especially the tangible services and empathy, to meet the tourists' needs, particularly Thai tourists who travel to the Thailand-Myanmar border, in Mae Sai, and Chiang Rai as well as tourists in other border cities in the future. Regarding the effects of SERVQUAL on the building up of the business image and tourist satisfaction, a good SERVQUAL will help increase behavioral intentions. Conversely, tourists will make a complaint when they get less qualified service. However, addressing the tourist complaint immediately can also increase their behavioral intentions as well.

\section{DISCUSSION}

The SERVQUAL affects company image creation and satisfies tourists. A good image will help tourists to form positive behavioral intention. If there is a positive image, the tourist will still make a complaint. However, if the complaint is solved directly, they will also have positive behavioral intention, which is associated with the findings from Ali \& Howaidee (2012). They explained that the service quality had an influence on the satisfaction of tourists. Similarily, Wang \& Chen (2012) found that 
the overall of service quality had a positive influence on tourists' behavioral intention. Subha \& Archana (2013) stated that the 5-dimensional elements, including trusty confidence, readiness in responding to a tourist, confidence in providing service, understanding and empathy to tourists, and materiality of services, have an influence to the satisfaction of passengers. In addition, Cao \& Chen (2011) found that if customers are not satisfied, they will complain. If the complaint is ignored, they would give up the service or never consume it again. In contrast, if the complaint was solved quickly, tourists would be happy and have more behavioral intention. They were also willing to help advertise or pass their words to other people and they themselves would return to visit.

The SERVQUAL has a direct positive effect on the business image, which is a claim consistent with the findings of Cao \& Chen (2011), who stated that SERVQUAL had an important effect on business image. Moreover, it had a direct positive effect on customer satisfaction which is related to what Liu \& Jang (2009) found that the food quality, service reliability, service response, shop atmosphere, shop decoration, and price affected directly customers' satisfaction. Moreover, it is related to the findings by Sivabrovornvatana, et al. (2005), which claimed that information and technology management were significant to service quality. It is also similar to the work of Park, et al. (2004), which found that passengers were satisfied with the SERVQUAL they got but that it is not related to Chen's (2008) study, which indicated that SERVQUAL did not directly affect passenger satisfaction but had an indirect relationship with the customer satisfaction through the values of airline services. This can be explained by the fact that these two studies were conducted with different models.

The business image has a directly positive effect on behavioral intentions. This finding is related to the work of Huang, et al. (2014), explaining that when the business image is good, users will have high behavior intention. The finding is also similar to that of Cao \& Chen (2011), who found that the business image has a direct effect on loyalty because the company image is important to create customers' behavioral intentions in real situations.

Satisfaction has a direct effect on complaints and the behavioral intentions. Satisfaction has a directly positive effect on the behavioral intentions, but it has complaints as an intermediate variable. Furthermore, complaints have a direct effect on the behavioral intentions, and this is consistent with Mohamad and Aliman (2013). They found that satisfaction had a positive influence on behavioral intention. Similarily, Cao \& Chen (2011) revealed that customers' satisfaction had a direct effect on complaints and that complaints had a directly positive effect on loyalty. In 
addition, satisfaction has an indirect effect on customers' behavioral intentions, but it does not fit with satisfaction and has no influence on loyalty. That is, tourist satisfaction has an effect on tourists' complaints and behavioral intentions.

\section{IMPLICATION}

The prominent findings of the present study is that tourism entrepreneurs in the border cities should focus on business image creation or satisfaction, which will develop the behavioral intentions of the tourists to travel there. If tourism entrepreneurs can effectively solve the problems as the tourists complain, behavioral intentions can definitely be increased.

\section{LIMITATION}

This research placed emphasis on only the context of the Thai-Myanmar border area. Furthermore, the data were collected using the cross-section approach.

\section{FUTURE STUDY}

This research focused on only Thai tourists who traveled to the Thai-Myanmar border area at Mae Sai District, Chiang Rai Province, Thailand, which is a small-sized sample. The future research should study other border cities, such as Thai-Laos border, the Thai-Malaysia border, and the Thai-Cambodia border. These borders were considered large-sized areas that should be considered in future research.

\section{REFERENCES}

Ali J. A., \& Howaidee, M. (2012). The impact of service quality on tourist satisfaction in jerash. Interdisciplinary Journal of Contemporary research in Business, 3, 164-187.

Cao C., \& Chen, J. (2011). An empirical analysis of the relationship among the service quality, customer satisfaction and loyalty of high speed railway based on structural equation model. Canadian Social Science, 7, 67-73. http://dx.doi.org/10.3968\%2Fj.css.1923669720110704.Z25

Caro, L. M., \& Garcia, J. A. M. (2007). Cognitive-affective model of consumer satisfaction. An exploratory study within the framework of a sporting event. Journal of Business Research, 60, 108-114. http://dx.doi.org/10.1016/j.jbusres.2006.10.008

Chen, C. F. (2008). Investigating structural relationships between service quality, perceived value, satisfaction, and behavioral intentions for air passengers : 
Evidence from Taiwan. Transportation Research, 42, 709-717. http://dx.doi.org/ 10.1016/j.tra.2008.01.007

Chen, L. (2012). Developing Hong Kong tourist satisfaction index using Bayesian structural equation modeling approach. The degree of Doctor of Philosophy, The Hong Kong Polytechnic University School of Hotel and Tourism Management.

DeVellis, B. (1991). Scale development. Newbury Park' CA: SAGE Publications, Inc,. Gillison, S. T. (2012). Satisfaction and shopping for others: revisiting expectancy disconfirmation theory. UMI ProQuest LLC, 1-182.

Goodman, J. (2006). Manage complaints to enhance loyalty. Quality Progress, 39, 28 34.

GrÖnroos, C. (1984). A service quality model and its marketing implications. European Journal of marketing, 18, 36-44. http://dx.doi.org/10.1108/EUM0000000004784

Huang, C. C., Yen S. W., Liu, C. Y., \& Huang P. C. (2014). The relationship among corporate social responsibility, service quality, corporate image and purchase intention. The international Journal of Organization Innovation. 6, 68-84.

Kotler, P. (2000). Marketing management. $14^{\text {th }}$ ed. N.J.: Prentice Hall.

Kotler, P. \& Keller, K. L. (2012). Marketing management. $14^{\text {th }}$ ed. USA. : Prentice Hall.

Liu, Y., \& Jang, S. (2009). Perceptions of Chinese restaurants in the U.S.A.: What affects customer satisfaction and behavioral intentions? International Journal of Hospitality Management, $28, \quad 338-348$. http://dx.doi.org/10.1016/j.ijhm.2008.10.008

Nunnally, C. (1978). Psychometric theory. $2^{\text {nd }}$ ed. New York : McGraw - Hill.

Oliver, R. L. (1980). A cognitive model of the antecedents and consequences of satisfaction decisions. Journal of marketing research, 17, 460-469. http://dx.doi.org/10.2307/3150499

Parasuraman, A., Zeithaml, V. A., \& Berry, L. L. (1988). SERVQUAL: A multipleitem scale for measuring consumer perceptions of service quality. Journal of Retailing, 64, 12-40.

Park, J. W., Robertson, R., \& Wu, C. L. (2004). The effect of airline service quality on passenger's behavioral intentions: A Korean case study. Journal of Air Transport Management, 10, 435-439. http://dx.doi.org/10.1016/j.jairtraman.2004.06.001

Rajesh, N., Ranjith, P V., Sumana, B., \& Charu, S. (2010) A study of service quality on banks with SERVQUAL model. SIES Journal of Management, 7, 35-45. 
Sivabrovornvatana, N., Siengthai, S., Krairit D., \& Paul, H. (2005). Technology usage, quality management system, and service quality in Thailand. International

Journal of Health Care Quality Assurance, 18, 413-423. http://dx.doi.org/10.1108/09526860510619417

Soekisno, H. (2001). A Comparison of public and private university students' expectations and perceptions of service quality in Jakata, Indonesia. ProQuest Information and Learning, 1-201.

Subha, M.V., \& Archana, R. (2013). Identifying the dimensions of service quality as antecedents to passenger satisfaction of Rajiv Gandhi International Airport. Journal of Contemporary Research in Management, 8, 25-33.

Tax, S. S., \& Brown, S. W. (2000). Service recovery, research insights and practices. In T.A., Swartz, \& D., Iacobucci, Handbook of services marketing and management, Thousand Oaks, CA: Sage. http://dx.doi.org/10.4135/9781452231327

Tipprasong, B. (2014). Beautiful places in "CHIANG RAI" SkyscraperCity. http://www.bangkokbiznews.com.

Wakefield, R. L., Sarmiento, A. H., \& Colson, R. H. (2001). Service quality. CPA Journal, 71, 58-60.

Wang, C. H., \& Chen, S. C. (2012). The relationship of full-service restaurant attributes, evaluative factors and behavioral intention. International Journal of Organizational Innovation, 15, 248-262.

Zeithaml, V. A. (1988). Consumer perceptions of price, quality, and value: A means end model and synthesis of evidence. Journal of Marketing, 52, 2-22. http://dx.doi.org/10.2307/1251446

Zeithaml, V. A. Berry, L. L., \& Parasuraman, A. (1996). The behavioral consequences of service Quality. Journal of Marketing, 60, 31-46. http://dx.doi.org/10.2307/1251929 